\title{
Correction to: Runners' metabolomic changes following marathon
}

\author{
Rengfei Shi ${ }^{*}$, Jin Zhang ${ }^{1}$, Biqing Fang ${ }^{1}$, Xiangyang Tian' ${ }^{1}$, Yu Feng ${ }^{1}$, Zepeng Cheng ${ }^{1}$, Zhongyu Fu',
} Jingjing Zhang ${ }^{1}$ and Jiaxi $\mathrm{Wu}^{2}$

\section{Correction to: Nutr Metab (2020) 17:19 \\ https://doi.org/10.1186/s12986-020-00436-0}

Following publication of the original article [1], the authors identified a missing reference.

Stander, Z., Luies, L., Mienie, L.J. et al. The altered human serum metabolome induced by a marathon. Metabolomics 14, 150 (2018).

https://doi.org/10.1007/s11306-018-1447-4

\section{Author details \\ 'School of Kinesiology, Shanghai University of Sport, 188 Hengren Road, Yangpu District, Shanghai 200438, China. ${ }^{2}$ Central Laboratories, Xuhui Central Hospital, Shanghai Clinical Research Center, Chinese Academy of Sciences, 966 Huaihai Middle Road, Shanghai 200031, China.}

Published online: 07 July 2020

\section{Reference}

1. Shi et al. Nutrition \& Metabolism (2020) Runners' metabolomic changes following marathon (2020) 17:19. DOl: https://doi.org/10.1186/s12986-02000436-0.

The original article can be found online at https://doi.org/10.1186/s12986020-00436-0

* Correspondence: rfshi@sus.edu.cn

'School of Kinesiology, Shanghai University of Sport, 188 Hengren Road, Yangpu District, Shanghai 200438, China

Full list of author information is available at the end of the article

(c) The Author(s). 2020 Open Access This article is licensed under a Creative Commons Attribution 4.0 International License, which permits use, sharing, adaptation, distribution and reproduction in any medium or format, as long as you give appropriate credit to the original author(s) and the source, provide a link to the Creative Commons licence, and indicate if changes were made. The images or other third party material in this article are included in the article's Creative Commons licence, unless indicated otherwise in a credit line to the material. If material is not included in the article's Creative Commons licence and your intended use is not permitted by statutory regulation or exceeds the permitted use, you will need to obtain permission directly from the copyright holder. To view a copy of this licence, visit http://creativecommons.org/licenses/by/4.0/ The Creative Commons Public Domain Dedication waiver (http://creativecommons.org/publicdomain/zero/1.0/) applies to the data made available in this article, unless otherwise stated in a credit line to the data. 